\title{
Polymorphism of CD1B Gene and Its Association with Yolk Immunoglobulin (IgY) Concentration and Newcastle Disease Antibody Titer in IPB-D1 Chicken
}

\author{
M. F. Al-Habib ${ }^{a}$, S. Murtini ${ }^{b}$, A. Gunawan ${ }^{a}$, N. Ulupi ${ }^{a}$, \& C. Sumantri ${ }^{a, *}$ \\ ${ }^{a}$ Department of Animal Production and Technology, Faculty of Animal Science, IPB University \\ (Bogor Agricultural University), \\ ${ }^{b}$ Department of Animal Disease and Veterinary Public Health, Faculty of Veterinary Medicine, IPB University \\ (Bogor Agricultural University), \\ Jalan Agatis, Kampus IPB Dramaga, Bogor 16680, Indonesia \\ *Corresponding author: csumantri12@gmail.com \\ (Received 14-01-2020; Revised 26-05-2020; Accepted 04-06-2020)
}

\begin{abstract}
The CD1B gene has an important role in the immune system of poultry by mediating antibody induction. The study aimed to identify the CD1B gene polymorphism and its association with the concentration of IgY and ND antibody titers in IPB-D1 chicken. As many as 111 of IPB-D1 chickens at 21 weeks old were used in this study. Polymorphism identification of the CD1B gene was made using the PCR Sequencing method, while the IgY and ND antibody titers were done using the ELISA and $\mathrm{HI}$ test, respectively. The associations of gene polymorphism with IgY and ND antibody titers were analyzed using the General Linear Model (GLM) procedure and Duncan`s Multiple Range test. The results show that there are 4 SNPs in exon 3, i.e., c.550 G>A, c.562 T>A, c.588 A>G, and c.612 C>G. All the SNPs are missense, silent mutations, and polymorphic. The c.550 G>A and c.562 T>A SNPs were in Hardy Weinberg's equilibrium and heterozygosity (0.054-0.252) condition, while the c.588 $A>G$ and c.612 C>G SNPs were not in equilibrium and their heterozygosity was low (0.072-0.252). The combination of 4 SNPs generated 8 haplotypes, i.e., haplotypes 1, 2, 3, 4, 5, 6, 7, and 8. Haplotypes 1, 2, and 8 had high frequencies (17.6\%-23.5\%). The c.588 $\mathrm{A}>\mathrm{G}$ and c.612 $\mathrm{C}>\mathrm{G}$ mutations were significantly associated $(p<0.05)$ with IgY concentration and c.562 $\mathrm{T}>\mathrm{A}$ were significantly associated $(\mathrm{p}<0.05)$ with ND antibody titers. The haplotypes 2 and 8 with a combination of c.588 $A>G$ and c.612 $C>G$ mutations had higher IgY concentration and ND antibody titers $(\mathrm{p}<0.05)$ compared to the other haplotypes. In conclusion, this study has identified the CD1B gene as a polymorphic and is associated with IgY concentration and ND antibody titers in IPB-D1 chicken.
\end{abstract}

Keywords: IPB-D1 chicken; CD1B; immunity; yolk immunoglobulin; ND antibody titer

\section{INTRODUCTION}

The IPB-D1 is a composite chicken developed from the crossbreed between F1 male (Pelung $x$ Sentul) and F1 female (Kampung x parent stock Cobb). The chicken has been released as a new local breed by the Ministry of Agriculture of the Republic of Indonesia (Reg. No.693/KPTS/PK.230/M/9/2019). The release of these chickens in the community which mostly will be maintained traditionally with uncontrolled and unhygienic conditions. These conditions require a good immune system of IPB-D1 chickens against viral and bacterial diseases.

Antibodies play an important role in the disease-resistance caused by bacterial, viral, fungal, parasitic, and protozoan infections (Abbas et al., 2018). An antibody is secreted by plasma cells as a humoral immune response that works effectively outside the cells in the body by neutralizing disease agents that finally causes the loss of the ability of the agent to infect cells in the body (Amro et al., 2018).

Yolk immunoglobulin $(\operatorname{Ig} Y)$ and Newcastle Disease (ND) antibody are important parameters of disease resistance in chickens. IgY is the major antibody in poultry, similar to IgG in mammals that functions in the major immune system (Munhoz et al., 2014; Antonysamy, 2018; Brujeni et al., 2019). ND antibody is specific to ND virus infections (Sharif \& Ahmad, 2018). Newcastle Diseases (ND) is a disease caused by Paramyxovirus serotype 1 (Kapczynski, Afonso, and Miller, 2013). Previous research mentions that $\operatorname{IgY}$ concentration correlates with Newcastle Disease (ND) antibody titers (Müller et al., 2015). The concentration of IgY and ND antibody titers can be used as parameters in the selection program and genetically, the productions of $\operatorname{IgY}$ and ND antibody are controlled by several genes.

The Cluster of Differentiation 1B (CD1B) is one of the important genes in antibody production, which 
plays a role in the presentation of lipid antigens to $\mathrm{T}$ helper cells (Taheri et al., 2019). The CD1B gene generates a CD1b molecule as a cofactor on the surface of APC (antigen-presenting cells) which interacted with $\mathrm{T}$ helper, so that antigen fragments presented by Major Histocompatibility Complex Class 2 (MHC II) can attach to $\mathrm{T}$ helper cell receptors. The mutations of $\mathrm{CD} 1 \mathrm{~B}$ gene cause changes in CD1b molecules produced that affect cell adhesion in the process of stimulating antibody production (Batuwangala et al., 2004; Haan et al., 2014; Maitra, 2019).

The CD1B gene in local chickens was significantly associated with IgY production (Zhang et al., 2015). Research in humans showed that the CD1B gene plays a role in antibodies production, self-antigen presentation, and autoimmunity (Li et al., 2011; Van Rhijn (Batuwangala et al., 2004; Haan et al., 2013; Bagchi (Batuwangala et al., 2004; Haan et al., 2016; Shahine et al., 2017). Other studies show that the CD1B gene is associated with the production of specific bacterial antibodies (antimicrobial) such as antimicrobial to Mycobacterium Tuberculosis and Salmonella Enteritidis (Briken et al., 2000; Gras et al., 2016).

To our knowledge, the single nucleotide polymorphisms information in exon 3 of CD1B genes and its association with IgY and ND antibody titers in IPB-D1 chickens have never been reported. The objective of this study was to identify the CD1B gene polymorphisms and their associations with IgY and ND antibody titers in IPB-D1 chickens. The results of this study can reinforce the selection program to obtain chicken populations with disease resistance through the CD1B gene as the genetic marker candidate.

\section{MATERIALS AND METHODS}

\section{Animals and Phenotypic Parameters}

The research has obtained the approval of ethical clearance and animal welfare from the Animal Care and Use Committee (ACUC) of IPB (Access No.: 163-2019 IPB). As many as 111 of IPB-D1 chickens (25 male and 86 female) were used in this study. Blood samples were collected at 21 weeks old. The IgY concentration was measured using the indirect ELISA method (Hnasko, 2015). The ND antibody titers were tested using the $\mathrm{HI}$ tests according to the OIE Manual of Standard Diagnostic Tests (Afonso et al., 2012).

\section{Gene Polymorphism}

Single Nucleotide Polymorphism (SNP) of the CD1B gene was used in this study according to SNP ID (Access No.: Gga_rs16057130) and Gene Bank (Access No.: NM_001024582) (Zhang et al., 2015). The primers were designed using the PrimerBLAST application (https://www.ncbi.nlm.nih.gov/ tools/primer-blast/) from NCBI (National Center for Biotechnology Information). The primers are as follows: 5'-TGGATCAGGGAAGGGGAAAC-3' (F), 5'GGGAGCAATAGGGTGGCTATC-3' (R) to produce
543 bp polymerase chain reaction (PCR) product. The amplification target is in the coding region in exon 3. DNA was extracted from fresh blood using the genomic DNA extraction mini kit (Geneaid ${ }^{\mathrm{TM}}$, Taiwan) according to the manufacturer's instructions. The PCR product was observed using a UV Transilluminator (Biorad ${ }^{\mathrm{TM}}$, California, USA). PCR products were sequenced by $1^{\text {st }}$ Base in Selangor, Malaysia. The results of sequencing data were processed using BLAST, Finch TV, and MEGA 7 programs (Hall, Biosciences, and Carlsbad, 2011).

\section{Data Analysis}

Gene polymorphism was analyzed by calculating allele and genotypes frequencies, chi-square values $\left(x^{2}\right)$ as well as observed $\left(\mathrm{H}_{\mathrm{o}}\right)$ heterozygosity and expected $\left(\mathrm{H}_{\mathrm{e}}\right)$ heterozygosity. The genotype and allele frequency was calculated according to Nei \& Kumar (2000). Hardy-Weinberg Equilibrium was analyzed using the chi-square values $\left(x^{2}\right)$ according to the formula of Nei \& Kumar (2000). Genetic heterozygosity was calculated using the frequencies of observational heterozygosity $\left(\mathrm{H}_{\mathrm{o}}\right)$ and expected heterozygosity $\left(\mathrm{H}_{\mathrm{e}}\right)$ (Weir, 1997).

The associations of the SNPs and haplotypes of CD1B gene with IgY and ND antibody titer were performed by General Linier Model (GLM) procedure using SAS 9.2 software (SAS Institute, Cary, NC, USA) and least means square values $(\bar{x})$ for genotypes and haplotypes were compared by Duncan`s Multiple Range test (Zhang et al., 2019). Significant associations were declared when $\mathrm{p}<0.05$. The mathematical model follows:

$$
Y_{i j}=\mu+G_{i}+S_{j}+e_{i j}
$$

where $Y_{i j}$ is the dependent variable (IgY, ND); $\mu$ is the mean square value; $G_{i}$ is the effect of $i^{\text {th }}$ genotype; $S j$ is the effect of the sex; and $e_{i j}$ is the random error.

\section{RESULTS}

\section{Amplification and Polymorphism of CD1B Gene}

The chicken CD1B gene is located on chromosome 16. The results of CD1B gene amplification of IPB-D1 chickens on annealing temperature conditions of $60 \mathrm{oC}$ for 20 seconds obtained a $543 \mathrm{bp}$ PCR product (Figure $1)$. The structure and amplification of CD1B gene sequences are presented in Figure 2.

The results of sequencing showed four SNPs (c.550 G>A (Gga_rs737509052), c.562 T>A (Gga_rs739487962), c.588 A>G (Gga_rs16057130), and c.612 C>G (Gga_ rs16057132)) on exon three (Figure 2). The c.562 $\mathrm{T}>\mathrm{A}$, c.588 A>G, and c.612 C>G SNPs indicated a transition mutation, while the c.550 G>A was a transversion mutation that replaced pyrimidine with purine base. SNPs (c.550 G>A, c.562 T>A, c.588 A>G, c.612 C>G) indicate changes in amino acids (missense mutation), i.e., c.550 $\mathrm{G}>\mathrm{A}$ valine $>$ isoleucine and c.562 $\mathrm{T}>\mathrm{A}$ serine $>$ threonine, and silent mutation occurs in c.588 $A>G$ and c.612 $C>G$ and does not change amino acids (leucine) (Table 1) (Figure 3). 


\section{Allele, Genotype Frequency, and Heterozygosity}

The results showed (Table 2) that the four SNPs were polymorphic with allele frequency value of more than $1 \%$. Genotypes with the highest frequency found in c.550 A>G, c.562 T>A, c.588 A>G, and c.612 C>G were GG, TT, AA, and CC, respectively. The c.550 A>G and c.562 $\mathrm{T}>\mathrm{A}$ were in the Hardy-Weinberg equilibrium
(Table 2), while the c.588 $\mathrm{A}>\mathrm{G}$ and c.612 C>G was not in the Hardy-Weinberg equilibrium. Observed heterozygosity and expected heterozygosity (Ho and He, respectively) values indicated that diversities of IPB-D1 chickens were low. The values in all SNPs were 0.0720.252 and 0.053-0.444 for $\mathrm{Ho}$ and $\mathrm{He}$, respectively (Table 2).

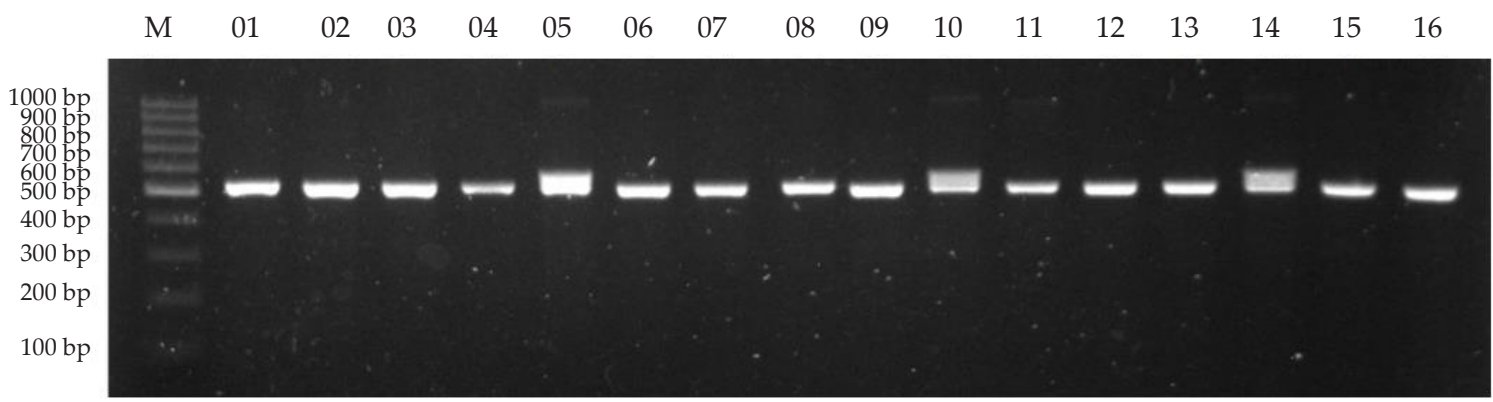

Figure 1. Results of CD1B gene PCR amplification in IPB-D1 chickens: M= DNA ladder 100 bp; 01.02 ... $16=$ sample codes.

A

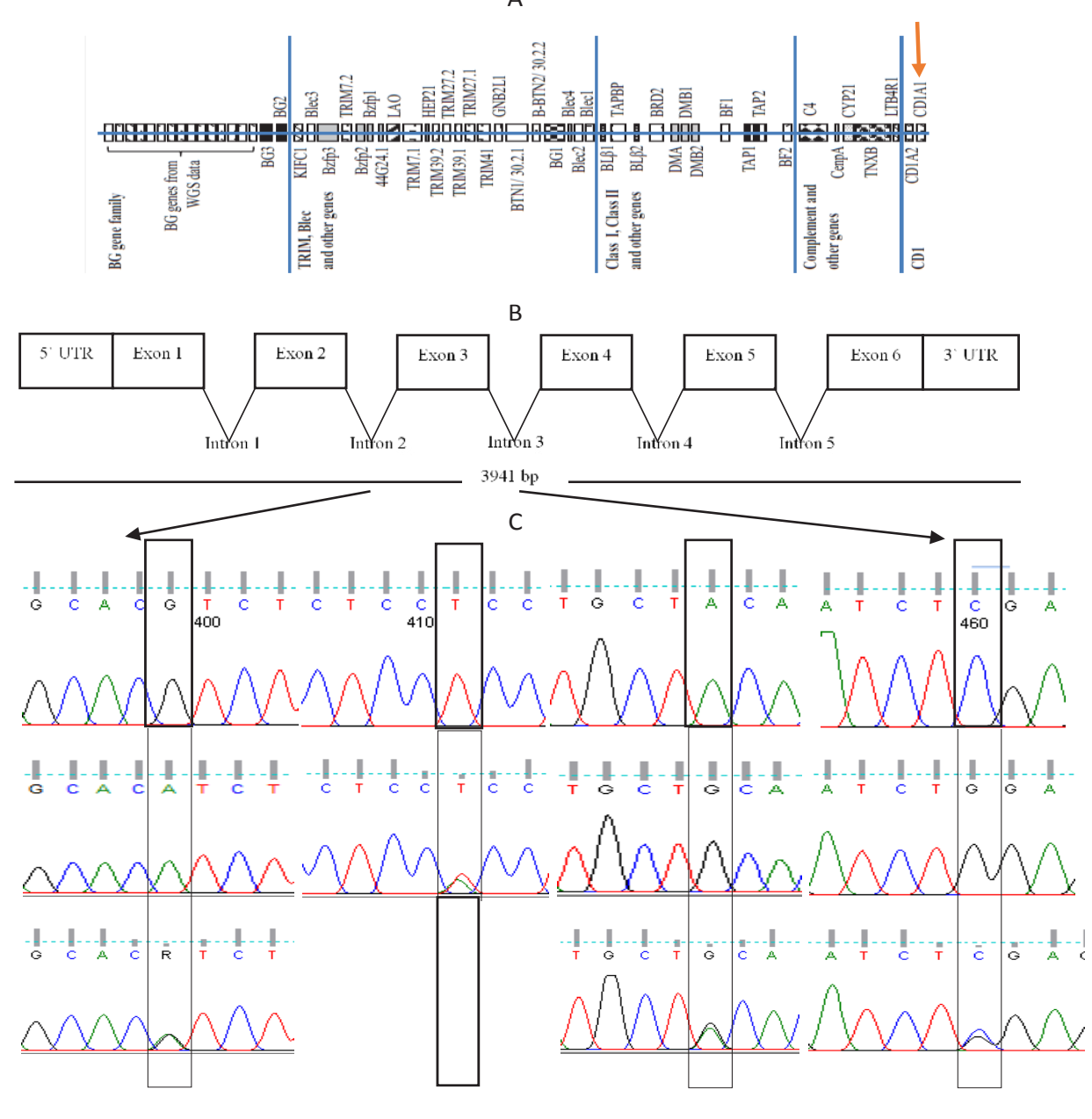
(a) SNP c.550 G>A
(b) SNP c.562 T>A
(c) SNP c.588 A>G
(d) SNP c.612 C >G

Figure 2. Schematic of SNPs position located in exon 3 of CD1B; (A) The location of the CD1B gene on chromosome 16 (Miller \& Taylor, 2016); (B) The CD1B gene structure (Access No.: NM_001024582); (C) SNPs position in CD1B gene. 
Table 1. Position of SNPs and type of substitutions of CD1B gene in IPB-D1 chicken

\begin{tabular}{ccccc}
\hline No. & DNA sequence change & Type of mutation & Amino acid change & Site mutation \\
\hline 1 & c.550 G $>$ A & Transversion & p.Val184Ile & Exon 3 \\
2 & c.562 T>A & Transition & p.Ser188Thr & Exon 3 \\
3 & c.588 G $>$ A & Transition & p.Leu196Leu & Exon 3 \\
4 & c.612 C $>$ G & Transition & p.Leu204Leu & Exon 3 \\
\hline
\end{tabular}

Note: c.550 G>A, c.562 T>A, c.588 G>A, and c.612 C>G = SNPs positions based on reference NM_001024582

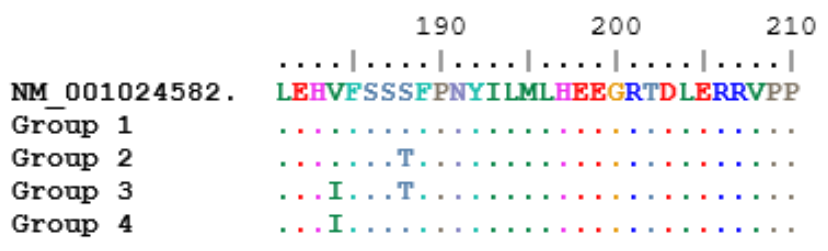

Figure 3. The group of amino acid changes in the CD1B gene in IPB-D1 chickens: Group 1= Haplotype 1, 2, 3; Group 2= Haplotype 4, 5; Group 3= Haplotype 6; Group 4= Haplotype $7,8$.

\section{CD1B Gene Haplotype Polymorphism}

All SNPs in the CD1B gene in IPB-D1 chickens generated eight haplotypes (Table 3). Haplotype 1, 2, and 8 showed the 3-highest frequency among all haplotypes found (Table 3). Haplotype 1 was a wild type based on NCBI (NM_001024582). Haplotype 2 obtained polymorphism in c.612 $\mathrm{A}>\mathrm{G}$, and haplotype 8 obtained polymorphism at c.550 G>A, c.588 A>G, and c.612 C>G. Allele $G$ was observed higher than allele A in SNP c.550 $\mathrm{G}>\mathrm{A}$, allele $\mathrm{G}$ was observed higher than allele $A$ in SNP c.588 G>A, and allele $\mathrm{G}$ was observed higher than allele A in SNP c.612 C>G, while T allele was higher than allele A in SNP c.562 T>A.

\section{Association of CD1B Gene with IgY and ND Antibody Titer}

The average of IgY concentration of IPB-D1 chickens at 21 weeks ranged from $8-11 \mathrm{mg} \mathrm{mL}^{-1}$. The $t$ test results showed (Table 4) that the IgY concentration of AG genotype of SNP c.588 G>A was significantly different $(\mathrm{p}<0.05)$ from GG genotype, and the IgY concentration of GG genotype of SNP c. 612 C>G was significantly different $(\mathrm{p}<0.05)$ from GC genotype. The AG genotype of SNP c.588 G>A produced the highest IgY concentration compared to SNPs and the other genotypes. There was no significant association between genotypes and IgY in the SNP c.550 G>A.

IPB-D1 chicken showed the protective $\mathrm{Ab}$ titer against NDV with the mean titer above $3 \log 2 \mathrm{HI}$ Units (OIE 2013). The association of CD1B genes with ND antibody titers shows that the TT genotype of SNP c.562 $\mathrm{T}>\mathrm{A}$ was significantly different $(\mathrm{p}<0.05)$ from AT (Table 4). Meanwhile, the genotypes of SNP c.550 G>A, SNP c.588 G>A, and SNP c.612 C>G. SNPs had no significant effect on ND antibody titers.

\section{Association of the CD1B Haplotype with IgY and ND Antibody Titer}

Polymorphism was found in 8 haplotypes of the CD1B gene at exon 3 (Table 3). The number of samples of haplotypes 5, 6, and 7 was low, so it cannot be associated with IgY and ND antibody titers. Haplotype 1 is a wildtype (Table 5) and it has low concentrations of IgY and ND. Haplotypes 2 and 8 showed the highest IgY concentrations among all haplotypes $(p<0.05)$. The IgY of haplotypes 2 and 8 were significantly different $(\mathrm{p}<0.05)$ from haplotype 1 and not statistically different from haplotypes 3 and 4 . The ND antibody titer of haplotype 4 was significantly different $(p<0.05)$ from haplotypes $1,2,3$, and 8 .

\section{DISCUSSION}

The IgY and ND antibody titer can be obtained from maternal antibody or direct exposure to the disease. The maternal antibody will gradually decrease with age and will increase again, depending on the disease exposure from the environment (Bernardini et al., 2017). Disease exposure induces IgY production through complex cell communications (APC, T, and B cells). Communication disorders or errors can affect the pro-

Table 2. Genotype frequency, allele frequency, heterozygosity values, and $\chi 2$ test CD1B gene on IPB-D1 chicken

\begin{tabular}{|c|c|c|c|c|c|c|c|c|}
\hline \multirow{2}{*}{$\begin{array}{r}\text { SNPs } \\
\text { c. } 550 \mathrm{G}>\mathrm{A}\end{array}$} & \multicolumn{3}{|c|}{ Genotype frequency } & \multicolumn{2}{|c|}{ Allele frequency } & \multirow[t]{2}{*}{ Ho } & \multirow[t]{2}{*}{$\mathrm{He}$} & \multirow[t]{2}{*}{$x^{2}$} \\
\hline & GG & AG & $\mathrm{AA}$ & G & $\mathrm{A}$ & & & \\
\hline & 0.74 & 0.24 & 0.02 & 0.86 & 0.14 & 0.252 & 0.247 & $0.056^{\mathrm{ns}}$ \\
\hline \multirow[t]{2}{*}{ c. $562 \mathrm{~T}>\mathrm{A}$} & $\mathrm{TT}$ & $\mathrm{AT}$ & AA & $\mathrm{T}$ & A & & & \\
\hline & 0.95 & 0.05 & 0.00 & 0.97 & 0.03 & 0.054 & 0.053 & $0.086^{\mathrm{ns}}$ \\
\hline \multirow[t]{2}{*}{ c. $588 \mathrm{G}>\mathrm{A}$} & GG & $\mathrm{AG}$ & AA & G & A & & & \\
\hline & 0.13 & 0.25 & 0.62 & 0.25 & 0.75 & 0.252 & 0.377 & $12.18^{\mathrm{s}}$ \\
\hline \multirow[t]{2}{*}{ c. $612 \mathrm{C}>\mathrm{G}$} & GG & GC & $\mathrm{CC}$ & G & $\mathrm{C}$ & & & \\
\hline & 0.30 & 0.07 & 0.63 & 0.33 & 0.67 & 0.072 & 0.444 & $77.919^{\mathrm{s}}$ \\
\hline
\end{tabular}

Note: $\chi 2(0.05 ; 1)=3.84 ; \mathrm{Ho}=$ observed heterozygosity; He= expected heterozygosity; $\mathrm{ns}=$ nonsignificant; $\mathrm{s}=$ significant. 
Table 3. Haplotype of the 3rd exon CD1B gene of IPB-D1 chicken

\begin{tabular}{|c|c|c|c|c|c|}
\hline \multirow{2}{*}{ Haplotype } & \multicolumn{4}{|c|}{ SNPs } & \multirow{2}{*}{ Frequency (n) } \\
\hline & c. $550 \mathrm{G}>\mathrm{A}$ & c.562 T>A & c. $588 \mathrm{~A}>\mathrm{G}$ & c. $612 \mathrm{C}>\mathrm{G}$ & \\
\hline Haplotype 1 & G & $\mathrm{T}$ & $\mathrm{A}$ & $\mathrm{C}$ & $26.1(29)$ \\
\hline Haplotype 2 & G & $\mathrm{T}$ & A & G & $36.0(40)$ \\
\hline Haplotype 3 & G & $\mathrm{T}$ & G & G & $6.3(7)$ \\
\hline Haplotype 4 & G & A & G & G & $3.6(4)$ \\
\hline Haplotype 5 & G & A & G & $\mathrm{C}$ & $0.9(1)$ \\
\hline Haplotype 6 & $\mathrm{~A}$ & $\mathrm{~A}$ & G & G & $0.9(1)$ \\
\hline Haplotype 7 & $\mathrm{~A}$ & $\mathrm{~T}$ & G & $\mathrm{C}$ & $2.7(3)$ \\
\hline Haplotype 8 & A & $\mathrm{T}$ & G & G & $23.4(26)$ \\
\hline Total & & & & & $100(111)$ \\
\hline
\end{tabular}

Note: n: number of samples.

Table 4. CD1B gene genotype association with IgY and ND antibody titer in IPB-D1 chicken

\begin{tabular}{|c|c|c|c|c|}
\hline \multirow{2}{*}{$\begin{array}{r}\text { SNPs } \\
\text { c. } 550 \mathrm{G}>\mathrm{A}\end{array}$} & \multirow[t]{2}{*}{ Antibody } & \multicolumn{3}{|c|}{ Genotype (n) } \\
\hline & & GG & GA & AA \\
\hline & $\operatorname{IgY~mg~mL-1~}$ & $9.98 \pm 2.35(53)$ & $10.70 \pm 2.70(20)$ & $8.76 \pm 0.00(1)$ \\
\hline & ND antibody titer Log 2 HI Unit & $3.00 \pm 2.38(53)$ & $3.34 \pm 2.14(20)$ & $1.00 \pm 0.00(1)$ \\
\hline \multirow[t]{3}{*}{ c. $562 \mathrm{~T}>\mathrm{A}$} & & $\mathrm{TT}$ & $\mathrm{AT}$ & AA \\
\hline & IgY mg mL-1 & $10.22 \pm 2.46(68)$ & $9.50 \pm 2.33(6)$ & $0.00 \pm 0.00$ \\
\hline & ND antibody titer Log 2 HI Unit & $3.04 \pm 2.14^{\mathrm{b}}(68)$ & $5.17 \pm 2.79^{a}(6)$ & $0.00 \pm 0.00$ \\
\hline \multirow[t]{3}{*}{ c. $588 \mathrm{~A}>\mathrm{G}$} & & AA & $\mathrm{AG}$ & GG \\
\hline & $\operatorname{IgY~mg~mL} L^{-1}$ & $9.91 \pm 2.52^{\mathrm{ab}}(46)$ & $11.67 \pm 2.02^{a}(15)$ & $9.30 \pm 1.96^{b}(13)$ \\
\hline & ND antibody titer Log 2 HI Unit & $3.20 \pm 1.93(46)$ & $2.80 \pm 2.62(15)$ & $3.77 \pm 2.62(13)$ \\
\hline \multirow[t]{3}{*}{ c. $612 \mathrm{C}>\mathrm{G}$} & & GG & GC & $\mathrm{CC}$ \\
\hline & $\operatorname{IgY} \mathrm{mg} \mathrm{mL} \mathrm{L}^{-1}$ & $10.80 \pm 2.25^{\mathrm{a}}(50)$ & $8.02 \pm 2.00^{\mathrm{b}}(4)$ & $8.99 \pm 2.70^{\mathrm{ab}}(25)$ \\
\hline & ND antibody titer Log 2 HI Unit & $3.14 \pm 2.40(50)$ & $4.00 \pm 1.83(4)$ & $3.25 \pm 1.74(25)$ \\
\hline
\end{tabular}

Note: means in the same row with different superscripts differ significantly $(\mathrm{p}<0.05)$; n: number of samples.

Table 5. CD1B gene haplotype association with IgY and ND antibody titer in IPB-D1 chickens

\begin{tabular}{ccc}
\hline Haplotype & IgY mg mL $L^{-1}(\mathrm{n})$ & $\begin{array}{c}\text { ND antibody titer log } \\
2 \text { HI Unit }(\mathrm{n})\end{array}$ \\
\hline Haplotype 1 & $8.52 \pm 1.77^{\mathrm{b}}(17)$ & $3.29 \pm 1.79^{\mathrm{b}}(17)$ \\
Haplotype 2 & $10.90 \pm 2.41^{\mathrm{a}}(28)$ & $3.18 \pm 2.06^{\mathrm{b}}(28)$ \\
Haplotype 3 & $9.33 \pm 1.80^{\mathrm{ab}}(3)$ & $1.33 \pm 0.58^{\mathrm{b}}(3)$ \\
Haplotype 4 & $9.54 \pm 1.20^{\mathrm{ab}}(4)$ & $5.75 \pm 3.30^{\mathrm{a}}(4)$ \\
Haplotype 5 & $12.78 \pm 0.00(1)$ & $0.00 \pm 0.00(1)$ \\
Haplotype 6 & $6.03 \pm 0.00(1)$ & $3.00 \pm 0.00(1)$ \\
Haplotype 7 & $16.80 \pm 0.00(1)$ & $2.00 \pm 0.00(1)$ \\
Haplotype 8 & $10.78 \pm 1.87^{\mathrm{a}}(18)$ & $3.00 \pm 2.54^{\mathrm{b}}(18)$ \\
\hline
\end{tabular}

Note: means in the same column with different superscripts differ significantly $(\mathrm{p}<0.05)$; $\mathrm{n}$ : number of samples.

duction of antibodies and affect the immune response of poultry.

The CD1 molecules play a role in immunity that consists of two main groups, namely CD1 group 1 (CD1A1) and CD1 group 2 (CD1A2). The CD1A1 molecule group consists of CD1a, CD1b, CD1c, and CD1e molecules, while the CD1A2 molecule group consists of molecules CD1d (Maruoka et al., 2005; Miller \& Taylor, 2016). The CD1b molecules play an important role in cell-cell communication as adhesion of $\mathrm{T}$ helper cells and APC (antigen-presenting cells) (Batuwangala et al., 2004; Taheri et al., 2019). The CD1b molecule functions as a cofactor on the surface of APC cells with T helper cells, so that antigen fragments presented by Major Histocompatibility Complex Class 2 (MHC II) can attach to T helper cell receptors (Maitra, 2019). CD1b molecules are controlled by the CD1B gene.

The study of the CD1B gene showed that the Ggars16057130 was associated with IgY in 720 population of Beijing-You chicken (Zhang et al., 2015). Referring to the study, the CD1B gene in exon 3 can be amplified along $543 \mathrm{bp}$ and found four SNPs in IPB-D1 chicken. The four SNPs are substitution mutations that cause changes in the structure of the DNA sequence (Figure 2). The mutations of DNA sequence affect the results of DNA transcription and RNA translation, which can affect protein coding (Figure 3). These types of SNPs (Table 1) consist of transition and transversion mutations. The transition mutation changes from purine to purine $(A>G)$ or pyrimidine base to pyrimidine $(C>T)$, while the transversion mutation changes from purine to pyrimidine $(A>T$ or $G>C)$. The function of gene regulation is influenced by transversion and transition mutations (Luo et al., 2016). Missense mutations that can change the shape of protein molecules expressed and affected 
the function and regulation of these proteins (Zhang et al., 2012). A silent mutation is a nucleotide mutation that does not change amino acids. Mutations also affect the mechanism of transcription and regulation of RNA, changing the structure of mRNA, and the speed of translation (Sauna \& Kimchi-Sarfaty, 2011).

The mutation was in Hardy-Weinberg equilibrium when chi-square values were smaller than the $\chi 2$ table (Wang \& Shete, 2017). The mutation in Hardy-Weinberg equilibrium means allele and genotype frequency are the same from generation to generation. The same frequency means that random marriages have occurred in the population and there are no other factors that cause genetic change (Allendorf \& Luikart, 2013). The heterozygosity value was the percentage of heterozygous individuals in the population (Nei \& Kumar, 2000). The Heterozygosity value is used to measure the level of genetic diversity in the population based on allele frequencies. If the observed heterozygosity (Ho) was higher than the expected heterozygosity $(\mathrm{He})$, it indicates that the genotype of the population is varied (Sharma et al., 2016). Based on the values of Ho and He (Table 2), which are not different, indicate that the genotype of IPB-D1 chicken is uniform. The value of heterozygosity is influenced by the number of samples and the frequency of genotypes and genetic markers used.

Haplotype is an alternative form of the gene due to mutations or a combination of SNPs in gene sequences (Delaneau et al., 2013). Gene mutations are influenced by genetic, environmental, and genetic environmental interactions. One of the genetic factors that influence gene variation is the chicken breed. Red Jungle Fowl chicken is the origin of Indonesian local chicken. Red Jungle Fowl chickens have higher genetic variation compared to purebred chickens (Wong et al., 2004). The results showed that IPB-D1 chicken as a composite of local chicken with a genetic composition of $25 \%$ purebred chicken, produced a high frequency of haplotype 1 (wild type/no mutation) (Table 3).

Yolk immunoglobulin ( $\operatorname{IgY}$ ) concentration is often associated as a general indicator of disease resistance. IgY concentrations in blood serum range from 5-15 mg $\mathrm{mL}^{-1}$ (Gaetani et al., 2017). Based on Table 3, the average IgY concentration of IPB-D1 chickens at 21 weeks ranged from $8-11 \mathrm{mg} \mathrm{mL}^{-1}$. The average concentration of IgY in native chickens was $10.07 \mathrm{mg} \mathrm{mL}^{-1}$ and in broilers $7.89 \mathrm{mg} \mathrm{mL}^{-1}$ (Asni, 2016). When compared to the existing literature, the concentration of IgY in IPB-D1 chickens is quite good, with an average IgY above broilers and similar to the other local chickens.

The results (Table 4) showed that the SNP c.588 $\mathrm{G}>\mathrm{A}$ affected $\mathrm{IgY}$ production $(\mathrm{p}<0.05)$ as was reported by Zhang et al. (2015) with SNP c.588 G>A in IPB-D1 chickens were significantly different $(p<0.05)$ from IgY. The same study conducted in local chickens (Sensi-1 Agrinak) obtained the same results, where the c.558 $\mathrm{G}>\mathrm{A}$ mutation was related to the concentration of $\mathrm{IgY}$, not related to the ND antibody titer (Al-Habib et al., 2020). Based on the literature study, the SNP c.588 A>G showed the same results in IPB-D1 chicken, Sensi-1 Agrinak, and Beijing-You local chicken, while the other SNPs in exon 3 in IPB-D1 chicken had not been studied before. The gene mutation has the potential to change the shape and affinity of the CD1b molecule, as was reported by Gras et al. (2016). As a result, APC and T helper cell communication is inhibited and causes the problems in B cell proliferation into plasma cells that produce antibodies (Maitra, 2019).

Vaccinated chickens have protective ability against ND viruses if the antibody titers are $\geq 4 \log 2$ HI Unit (OIE 2013), whereas chickens that were not vaccinated were protective against ND virus if they had antibody titers $\geq 3 \log 2$ HI Unit. The results of the present study showed that the IPB-D1 chicken with vaccination at the age of 3 days and 3 weeks obtained a protective antibody titer against the ND virus (Table 4). The results of the association showed that genotypes with protective against ND viruses in SNP c.550 G>A, c.562 T>A, c.588 $\mathrm{G}>\mathrm{A}$, and c.612 C>G were GG and GA, TT and AT, AA and GG, and GG, as well as GC and CC, respectively, while the AG genotype in c.588 is not protective against ND viruses. The results of the association showed that genotypes with protective against ND viruses in SNP c.550 G>A, c.562 T>A, c.588 A>G, and c.612 C>G were GG and GA, TT and AT, AA and GG, GG, GC, and CC, respectively. While the $A G$ genotype in c.588 $A>G$ is not protective against ND viruses. The SNP c.588 G>A showed no association with $\operatorname{Ig} Y(p>0.05)$, as previous studies on local chickens (Sensi-1 Agrinak) showed the same results (Al-Habib et al., 2020).

IgY concentration and ND antibody titer were positively correlated (Brujeni et al., 2019). The genotypes in SNP c.550 G>A and c.562 T>A showed mean IgY and ND antibody titers, which were positively correlated, where genotypes with high IgY concentrations then the ND antibody titers produced were also high. However, antibody concentrations show the opposite profile in SNP c.588 G>A and c.612 C>G, where genotypes with high IgY concentrations produce low ND antibody titers. The results in Table 4, showed that ND antibody titers did not differ significantly between genotypes. The insignificant difference means that the body does not overreact in producing specific ND virus antibodies so that chickens affected by ND viruses and those that are not exposed by ND viruses have the same antibodies production that is not significantly different. The continuing production of ND antibody after more than 3 weeks of vaccination can be used as an indication of the presence of virus in the body. The presence of viruses can be related to the vaccination or the exposure of virus from the environment, and it is useful to stimulate the immune system to produce ND-specific antibodies. The IPB-D1 chicken has a protective antibody category. The result of this study is in agreement with the result of Pagala et al. (2013) that native chickens have a genetic potential to be resistant to virus infection.

The IgY concentration above $9.3 \mathrm{mg} \mathrm{mL}^{-1}$ can be categorized as a high concentration (Setyawati et al., 2019). The average results in Table 5 show that the IgY concentrations of the haplotypes 2, 3, 4, and 8 are in the high category, while the haplotype 1 is in the medium category. Haplotype 4 shows a high IgY concentration and the ND antibody titer is relatively protective. The results of the association show (Table 5) that the muta- 
tion at SNPs are useful and able to induce Ab productions, while haplotype 1 without mutations obtains normal antibody concentrations, haplotype 2 with SNP c.612 C>G affects the production of increasing IgY but low titer of ND antibody. Haplotypes 8 and 4 with a combination of mutations provide a lot of responses in the forms of high IgY concentrations and high ND antibody titers. SNP c.588 G>A and SNP c.612 C>G on G allele carry good disease-resistance properties with the presence of these mutations increase the production of IgY and ND antibody titers.

\section{CONCLUSION}

Association of CD1B in exon 3 gene polymorphism with IgY concentration and Newcastle Disease antibody titer have been revealed for the first time which provided evidence that $\mathrm{CD} 1 \mathrm{~B}$ might be an important as predictors of immune resistance in chicken. Present finding showed that in haplotypes 2,4 , and 8 was potential to be developed as genetic marker in the selection program for production high IgY concentrations and ND antibody in IPB-D1 chicken.

\section{CONFLICT OF INTEREST}

Asep Gunawan and Cece Sumantri serve as editor of the Tropical Animal Science Journal, but have no role in the decision to publish this article. The Authors also declare that there is no conflict of interest with any financial, personal, or other relationships with other people or organizations related to the material discussed in the manuscript.

\section{ACKNOWLEDGEMENT}

We thank to Ministry of Research, Technology and Higher Education (Indonesia), which has financed this research through the collaboration of World Class Research, with the contract number: 121/SPH/LT/ DPRM/2019.

\section{REFERENCES}

Abbas, A.K., H. Andrew, Lichtman, \& P. Shiv. 2018. Cellular and Molecular Immunology, $9^{\text {th }}$ ed. Elseiver, United Kingdom.

Afonso, C. L., P. J. Miller, C. Grund, G. Koch, B. Peeters, P. W. Selleck, \& G. B. Srinivas. 2012. Newcastle Disease (Infection with Newcastle Disease Virus). In: World Organization for Animal Health, editor. Manual of diagnostic tests and vaccines for terrestrial animals. $7^{\text {th }}$ ed. OIE. pp. 555-574. https://doi.org/10.1080/713655022

Al-Habib, M.F., S. Murtini, A. Gunawan, N. Ulupi, \& C. Sumantri. 2020. Association of polymorphism of 3 ekson (c.248 A>G) CD1B genes with IgY and ND titter in Sensi-1 Agrinak Chicken. JIPTHP. 06:113-120. https://doi. org/10.29244/jipthp.8.1.30-35

Allendorf, F.W. \& G. Luikart. 2013. Conservation and the Genetics of Population. $2^{\text {nd }}$ ed. Wiley-Blackwell, United Kingdom

Amro, W.A., W. Al-Qaisi, \& F. Al-Razem. 2018. Production and purification of $\operatorname{IgY}$ antibodies from chicken egg yolk. J. Genet. Eng. Biotechnol. 16:99-103. https://doi. org/10.1016/j.jgeb.2017.10.003

Antonysamy, M. 2018. Applications of Chicken Egg Yolk Antibodies (Igy) in Healthcare: A Review. Biomed. J. Sci \& Tech. Res. 2. https://doi.org/10.26717/BJSTR.2017.01.000649

Asni, S.N. 2016. Comparison of the productivity of IgY isolation from domestic chicken eggs, kampong chicken eggs and duck eggs with the PEG-precipitation method. JPST. 5: $1-7$.

Bagchi, S., S. Li, \& C.R. Wang. 2016. CD1b-Autoreactive T cells recognize phospholipid antigens and contribute to antitumor immunity against a CD1b+ T cell lymphoma. OncoImmunology 5: 9. https://doi.org/10.1080/216240 2X.2016.1213932

Batuwangala, T., D. Shepherd, S. D. Gadola, K. J. C. Gibson, N. R. Zaccai, A. R. Fersht, G. S. Besra, V. Cerundolo, \& E. Y. Jones. 2004. The crystal structure of human CD1b with a bound bacterial glycolipid. J. Immunol. 174:2382-2388. https://doi.org/10.4049/jimmunol.172.4.2382

Bernardini, R., R. Aufieri, A. Detcheva, S. Recchia, R. Cicconi, M. Amicosante, C. Montesano, P. Rossi, H. K. Tchidjou, B. Petrunov, G. Orefici, \& M. Mattei. 2017. Neonatal protection and preterm birth reduction following maternal group B Streptococcus vaccination in a mouse model. J. Matern. Fetal. Neonatal. Med. 30: 2844-2850. https://doi.or $\mathrm{g} / 10.1080 / 14767058.2016 .1265932$

Briken, V., R. M. Jackman, G. F.M. Watts, R. A. Rogers, \& S. A. Porcelli. 2000. Human CD1b and CD1c isoforms survey different intracellular compartments for the presentation of microbial lipid antigens. J. Exp. Med. 192:281-288. https://doi.org/10.1084/jem.192.2.281

Brujeni, G. N, M. Hassanzadeh, H. Al-Karagoly, T. Tolouei, \& A. Esmailnejad. 2019. Evaluation of humoral immune responses to enterotropic lentogenic VG/GA vaccine of Newcastle Disease in commercial Turkey poults (Meleagris gallopavo). Acta. Vet. Scand. 61:1-6. https://doi.org/10.1186/ s13028-019-0476-y

Delaneau, O., B. Howie, A. J. Cox, J. F Zagury, \& J. Marchini. 2013. Haplotype estimation using sequencing reads. AJHG. 93:687-696. https://doi.org/10.1016/j.ajhg.2013.09.002

Gaetani, C., E. Ambrosi, P. Ugo, \& L. M. Moretto. 2017. Electrochemical Immunosensor for detection of $\operatorname{IgY}$ in food and food supplements. Chemosensors 5: 10. https:// doi.org/10.3390/chemosensors5010010

Gras, S., I. V. Rhijn, A. Shahine, T. Y. Cheng, M. Bhati, L. L. Tan, H. Halim, K. D. Tuttle, L. Gapin, J. L. Nours, D. B. Moody, \& J. Rossjohn. 2016. T cell receptor recognition of CD1b presenting a mycobacterial glycolipid. Nat. Commun. 7: 1-12. https://doi.org/10.1038/ncomms13257

Haan, J. M.M. D., R. Arens, \& M. C. V. Zelm. 2014. The activation of the adaptive immune system: cross-talk between antigen-presenting cells, T cells and B cells. Immunol. Lett. 162: 103-112. https://doi.org/10.1016/j.imlet.2014.10.011

Hnasko, R. 2015. ELISA: Methods and Protocols. ELISA: Methods and Protocols. Springer. New York. p.51-59. https://doi.org/10.1007/978-1-4939-2742-5

Kapczynski, D.R., C.L. Afonso, \& P.J. Miller. 2013. Immune responses of poultry to newcastle disease virus. DCI. 41:447453. https://doi.org/10.1016/j.dci.2013.04.012

Li, S., H. J. Choi, K. Felio, \& C. R. Wang. 2011. Autoreactive CD1b-restricted T cells: A new innate-like T-cell population that contributes to immunity against infection. Blood. 118: 3870-3878. https://doi.org/10.1182/blood-2011-03-341941

Luo, G. H., X. H. Li, Z. J. Han, Z. C. Zhang, Q. Yang, H. F. Guo, \& J. C. Fang. 2016. Transition and transversion mutations are biased towards GC in transposons of chilo suppressalis (Lepidoptera: Pyralidae). Genes. https://doi.org/10.3390/ genes7100072

Maitra, R. \& N. Elkaim. 2019. CD1b in Review: High TCR specificity limits auto-reactivity. Biomed. J. Sci. 
\& Tech. Res. 12:9628-9634. https://doi.org/10.26717/ BJSTR.2019.12.002328

Maruoka, T., H. Tanabe, M. Chiba, \& M. Kasahara. 2005. Chicken CD1 genes are located in the MHC: CD1 and endothelial protein $C$ receptor genes constitute a distinct subfamily of class-I-like genes that predates the emergence of mammals. Immunogenetics. 57: 590-600. https://doi. org/10.1007/s00251-005-0016-y

Miller, M.M. \& R. L. Taylor. 2016. Brief review of the chicken major histocompatibility complex: the genes, their distribution on chromosome 16, and their contributions to disease resistance. Poult. Sci. 95: 375-392. https://doi. org/10.3382/ps/pev379

Müller, S., A. Schubert, J. Zajac, T. Dyck, \& C. Oelkrug. 2015. IgY antibodies in human nutrition for disease prevention. Nutrition Journal 14:1-7. https://doi.org/10.1186/ s12937-015-0067-3

Munhoz, L. S., G. D. Vargas, G. Fischer, M. Lima, P. A. Esteves, \& S. O. Hübner. 2014. Avian IgY antibodies: characteristics and applications in immunodiagnostic. Ciência. Rural. 44: 153-160. https://doi.org/10.1590/s0103-84782014000100025

Nei, M. \& S. Kumar. 2000. Molecular Evolution and Phylogenetics. Oxford Univ Pr. New York.

OIE (Office International Des Epizooties). 2013. Manual of Diagnostic Tests and Vaccines for Terrestrial Animals. Capter 2.3.14. Newcastle Disease. World Organisation for Animal Health. pp. 1-9.

Pagala, M. A., Muladno, C. Sumantri, \& S. Murtini. 2013. Association of $\mathrm{Mx}$ gene genotype with antiviral and production traits in tolaki chicken. Poult. Sci. 12:735-739. https://doi.org/10.3923/ijps.2013.735.739

Sauna, Z. E., \& C. Kimchi-Sarfaty. 2011. Understanding the contribution of synonymous mutations to human disease. Nat. Rev. Genet. 12:683-691. https://doi.org/10.1038/ nrg3051

Setyawati, M. P., N. Ulupi, S. Murtini, \& C. Sumantri. 2019. Production performance, reproduction and immunity of sentul hens at different IgY concentrations. Buletin Peternakan 43:17-21. https://doi.org/10.21059/buletinpeternak.v43i1.35180

Shahine, A., I. Van Rhijn, T. Y. Cheng, S. Iwany, S. Gras, D. B. Moody, \& J. Rossjohn. 2017. A molecular basis of human T cell receptor autoreactivity toward self-phospholipids. Sci. Immunol. 2. https://doi.org/10.1126/sciimmunol.aao1384
Sharif, A. \& T. Ahmad. 2018. Preventing Vaccine Failure in Poultry Flocks. In Immunization - Vaccine Adjuvant Delivery System and Strategies. Intech Open. United Kingdom. p.79-91. https://doi.org/10.5772/ intechopen.79330

Sharma, R., B. Kumar, R. Arora, S. Ahlawat, A. K. Mishra, \& M. S. Tantia. 2016. Genetic diversity estimates point to immediate efforts for conserving the endangered tibetan sheep of India. Meta. Gene. 8:14-20. https://doi.org/10.1016/j. mgene.2016.01.002

Taheri, M., H. Danesh, F. Bizhani, G. Bahari, M. Naderi, \& M. Hashemi. 2019. Association between genetic variants in CD1A and CD1D genes and pulmonary tuberculosis in an Iranian population. Biomed. Rep. 10: 259-265. https://doi. org/10.3892/br.2019.1201

Van Rhijn, I., D. Ly, \& D. B. Moody. 2013. CD1a, CD1b, and CD1c in Immunity against Mycobacteria. Advances in Experimental Medicine and Biology. Springer. New York. https://doi.org/10.1007/978-1-4614-6111-1_10

Wang, J. \& S. Shete. 2017. Testing departure from HardyWeinberg proportions methods. Mol. Biol. 850:77-102. https://doi.org/10.1007/978-1-4939-7274-6_6

Weir, B. S. 1997. Genetic Data Analysis II. : Method for Discrete Population Genetic Data. $2^{\text {nd }}$ ed. Sinauer Associates, Sunderland. https://doi.org/10.2307/2533134

Wong, G. K. S., B. Liu, J. Wang, R. P. M. A. Crooijmans, J. J. van der Poel, H. Bovenhuis, \& M. A. M. Groenen. 2004. A genetic variation map for chicken with 2.8 million singlenucleotide polymorphisms. Nature 432:717-722. https:// doi.org/10.1038/nature03156

Zhang, X. X., J. S. Ran, T. Lian, Z. Q. Li, C. W. Yang, X. S. Jiang, H. R. Du, Z. F. Cui, \& Yi Ping Liu. 2019. The Single nucleotide polymorphisms of myostatin gene and their associations with growth and carcass traits in daheng broiler. Rev. Bras. Cienc. Avic. 21:2-3. https://doi. org/10.1590/1806-9061-2018-0808

Zhang, L., P. Li, R. Liu, M. Zheng, Y. Sun, D. Wu, Y. Hu, J. Wen, \& G. Zhao. 2015. The identification of loci for immune traits in chickens using a genome-wide association study. Plos One. 10:1-16. https://doi.org/10.1371/journal. pone.0117269

Zhang, Z., M. A. Miteva, L. Wang, \& E. Alexov. 2012. Analyzing effects of naturally occurring missense mutations. Comput. Math. Methods. Med. 2012:1-15. https://doi. org/10.1155/2012/805827 